disease and fulminant hepatitis in those infected with hepatitis B virus. ${ }^{\text {is }}$

Immunisation of these two populations poses important problems. Homosexual men could most readily be immunised through departments of genitourinary medicine, and vaccine uptake is likely to be high. The need for serological screening, immunisation, and follow up for subsequent doses will, however, inevitably require additional resources, which should include health education. The cost effectiveness of such a policy has been well argued..$^{16}$ The men may also need to be revaccinated since antibodies may disappear in $15 \%$ and wane to non-protective titres in $27 \%$ after five years. ${ }^{17}$ The task of protecting the illicit drug abuser presents an even greater challenge. Immunisation through departments of genitourinary medicine or addiction centres is a possibility, although great emphasis on community follow up will be necessary for the policy to be successful. Failure to act promptly can lead only to an increase in the medical and economic burden of this preventable but incurable disease.

ROGER G FINCH

Consultant and Senior Lecturer in Microbial Diseases,

City Hospital and

University of Nottingham,

Nottingham NG5 1PB

1 Polakoff S. Acute viral hepatitis B: laboratory reports 1980-4. Br Med f 1986;293:37-8.

2 Woolf IL, Willias R. Significance of persistent HBs antigenaemia. Br Med f 1976;ii:807-8.

3 Yellowlees H, Poole AAB. Hepatitis B oaccine: guidance on use. London: DHSS, 1982. (CMO (82) 13.)

4 Triger DR. Hepatitis B immunization: experience in a provincial centre. Health Trends 1984;16:41-3.

5 Stevens CE, Taylor PE, Rubinstein P, et al. Safety of hepatitis B vaccine. $N$ Engl $\mathcal{J}$ Med 1985;312:375-6.

6 Papaevangelou G, Kallinikos G, Roumelioutou A, Politou K. Risk of AIDS in recipients of hepatitis b vaccine. N Engl I Med 1985;312:376-7.

7 Kessler $H$, Chase $R$, Harris R, Jensen D, Levin S. HTLV-III antibodies after hepatitis vaccination. Lancet 1985;i:1506-7.

8 Smiction $C$. An 279 patients with chronic hepatitis B liver disease. [Abstract.] Hepatology 1981;1:548.

9 disease. [Abstract.] Hepatology $1981 ; 1: 548$. In: Cohen S, Soloway RS, eds. Chronic active liver disease. London: Churchill Livingstone, In: Cohen $S$,
$1983: 73-80$.

10 Flewett TH. Can we eradicate hepatitis B? BrMed I 1986;293:404-5.

11 Zuckerman AJ. Priorities for immunisation against hepatitis B. Br Med $\mathcal{Y}$ 1982;284:686-8.

12 Coleman JC, Waugh M, Dayton R. Hepatitis B antigen and antibody in a male homosexua population. Brf Vener Dis 1977;53:132-4.

13 Tedder RS, Cameron CH, Wilson-Crooe R, et al. Contrasting patterns and frequency of antibodies to the surface, core and $e$ antigens of hepatitis $B$ virus in blood donors and in homosexual patients. F Med Virol 1980;6:323-32.

14 Perrillo RP, Regenstein FG, Roodman ST. Chronic hepatitis B in asymptomatic homosexual men with antibody to the human immunodeficiency virus. Ann Intern Med 1986;105:382-3.

15 Smedile A, Verme G, Cargnel A, Dentico P, Opolon P, Vergani D. Influence of delta infection on severity of hepatitis B. Lancet 1982;ii:945-7.

16 Adler MW , Belsey EM, McCuthan JA, Mindel A. Should homosexuals be vaccinated against hepatitis B? Cost and benefit assessment. BrMed I 1983;286:1621-4.

17 Hadler SC, Francis DP, Maynard JE, et al. Long-term immunogenicity and efficacy of hepatitis B vaccine in homosexual men. $N$ Engl f Med 1986;315:209-14.

\section{The locked in syndrome}

The first description of the locked in syndrome may not have been by a doctor but by a writer-Emile Zola in Thérèse Raquin in $1868 .{ }^{12}$ Camille is murdered by Thérèse and her passionate, adulterous lover, Laurent. Saddened by her son's death the pitiful mother, Madame Raquin, has a stroke: "Her tongue turned to stone. Her hands and feet stiffened. She was struck dumb and motionless." After a partial respite "she had only the language of her eyes, and her niece had to guess what she wanted." Later "she could communicate quite easily with that imprisoned mind buried alive in a dead body. . . . She had learnt to use her eyes like a hand or a mouth, to ask and give thanks, and in a strange way made up for the organs she had lost." She later discovered the lovers' treachery in murdering her son and then "made frantic efforts to ... put all her hatred into her eyes." The wicked couple are eventually driven to take their own lives bye poison. "Madame Raquin, stiff and silent, contemplate them at her feet, unable to feast her eyes enough, eyes thas: crushed them with brooding hate."

It was more than a century later that Plum and Posnem introduced the term the "locked in syndrome."3 Patient with the syndrome are tetraplegic and mute but have pre:served sentient consciousness. They are thus immobile and locked in but can communicate by blinking and vertical eye movements. ${ }^{45}$ They are aptly described as "de-efferented.'을 The condition is different from coma, the "persistent vegetative state," and akinetic mutism.

Coma, "a state of unrousable unresponsiveness," is thळ best known of the states of altered consciousness. It $\vec{S}$ principal cause is a disturbance of the alerting wakefulness mechanisms that operate through the ascending reticulafs formation in the brain stem and diencephalon. ${ }^{3}$ This happens? when a sizable lesion in a hemisphere (a mass, haematoma infarct, or oedema) encroaches on, distorts, or compresseso the rostral brain stem. Infratentorial lesions may cause comás by direct pressure on the brain stem; metabolic or anoxiof insults can produce the same end result.

After severe brain damage consciousness may return usually in two to four weeks, but the victim may be left in $\$$ persistent vegetative state. ${ }^{6}$ This describes a state in which the patient survives for months or years and is awake and moves a little but shows no sign of conscious intelligence Most die of the complications of immobility rather than front the widespread damage to the neocortex.

"Akinetic mutism" (or coma vigil) was first described byo0 Cairns and others in 1941 in a patient with a epidermoid cyst of the third ventricle. ${ }^{7}$ These patients lie motionlesso mindless, and unaware of their surroundings but show sleep wake cycles. They may be capable of reflex movement withdrawing from a painful stimulus, and may make semiळ purposeful movements but usually cannot be stimulated to do so. The condition may be caused by tumours of the thirc ventricle or by large lesions-most commonly traumatic anoxic, or vascular ${ }^{8}$ - affecting both hemispheres and whiclộ. have destroyed the frontal cortex,${ }^{9}$ basal ganglia, thalamus, ${ }^{10}$ or diencephalon." With such massive damage very few patients survive.

The locked in syndrome usually results from infarction haemorrhage, or demyelination in the ventral pons oß medulla: the lesion paralyses the pyramidal tracts to the limbs and the lower cranial nerves but spares the tegmentum? thereby preserving the supranuclear pathway to the oculaf motor mechanism. ${ }^{12}$ Consciousness depends on the sparing of the upper pontine tegmentum above the level of the trigeminal nucleus. ${ }^{35}$

Associated brain stem signs are pointers to more precise localisation, which admittedly has little therapeutic imo portance. Electroencephalograms are usually normalo consistent with the wakeful state. ${ }^{512}$ Brain stem evoke $\phi$ potentials show loss or impaired amplitude of waves IV and $\mathrm{V}$, indicating damage to the tegmentum. ${ }^{13}$ Lateral gaze is often lost, but vestibulo-ocular reflexes tested by ice wate irrigation may be retained. Destruction of the descendin supranuclear path for voluntary gaze is the likely mechanism for this dissociation between voluntary and reflex movement The occurrence of peculiar rhythmic but involuntary downo ward movements of the eyes called "ocular bobbing localises the lesion to the pons. ${ }^{514}$ 
Further clues to localisation may be provided by characteristic patterns of disordered respiration seen in patients with the locked in syndrome and lesions in the brain stem. ${ }^{3}$ Automatic (eupnoeic) breathing shows the disconnection of the medullary centres from higher brain stem control. Lesions of the tegmentum at the midbrain pontine level may cause "central neurogenic hyperventilation," which resembles the deep, rapid, Kussmaul pattern of metabolic acidosis. Either the irregular, unpatterned breathing of "ataxic respiration" or the prolonged, inspiratory breath holding characterising "apneustic breathing" may occur in patients with lesions of the lower pontine tegmentum.

Recognition of the locked in state is important if casual remarks at the bedside are not to be the cause of grave hurt and mental anguish to a conscious patient. ${ }^{\text {is }}$ Patients thought to be in a coma should be commanded to raise their eyes and to blink; only in this way will the awareness of the alert but helpless patient be discovered. Most patients survive for only a few weeks or months, but a few are condemned to this conscious hell for over a year.

\section{J M S PEARCE}

Consultant Neurologist

Hull Royal Infirmary,

Hull HU3 2JZ

1 Thompson AJ, Martin EA. Zola and the locked-in syndrome. Neurology 1984;34:1212.

2 Zola E. Thérèse Raquin. Tancock L, transl. London: Penguin Classics, 1982. (Published originally in 1868.)

3 Plum F, Posner JB. The diagnosis of stupor and coma. 2nd ed. Philadelphia: F A Davis, 1972.

4 Nordgren RE, Markesbery WR, Fukuda K, Reeves AG. Seven cases of cerebral medullary disconnexion: the locked in syndrome. Neurology 1971;21:1140-8.

5 Chase TN, Moretti L, Prensky AL. Clinical and electroencephalographic manifestations of vascular lesions of the pons. Neurology 1968;18:357-68.

6 Jennett WB, Plum F. The persistent vegetative state. Lancet 1972;i:734-7.

7 Cairns H, Oldfield RC, Pennybacker JB, Whitteridge D. Akinetic mutism with an epidermoid cyst of the third ventricle. Brain 1941;64:273-90.

8 Kemper TL, Romanul FCA. State resembling akinetic mutism in basilar artery occlusion. Neurology 1967:17:74-80.

9 Barris RW, Schuman HR. Bilateral anterior cingulate gyrus lesions. Neurology 1953;3:44-52.

10 Skutety FM. Clinical and experimental aspects of akinetic murism. Arch Neurol 1968;19:1-14.

11 Segarra JM. Cerebral vascular disease and behaviour. 1 . The syndrome of the mesencephalic artery (basilar artery infarction). Arch Neurol 1970;22:408-18.

12 Hawkes CH. Locked-in syndrome: report of seven cases. Br Med f 1974;ii:379-82.

12 Hawkes CH. Locked-in syndrome: report of seven cases. Br Med J 1974;ii:379-82. Seales DM, Torkelson RD, Shuman RM, et al. Abnormal brainstem auditory
and neuropathology in "locked-in syndrome." Neurology 1981;31:893-6.

14 Tijssen CC, Ter Bruggen JP. Locked-in syndrome associated with occular bobbing. Acta Neurol Scand 1986;73:444-6.

15 Virgile RS. Locked-in syndrome. Clin Neurol Neurosurg 1984;86:275-9.

\section{Black-white health gap in the USA}

A recent report from the secretary of the Department of Health and Human Services draws attention to the continuing disparity between the health of whites and blacks in the United States.' Since at least the turn of the century blacks have become ill more often and died younger than whites. A black male born in 1970 has a life expectancy 6.7 years less than his white counterpart, ${ }^{2}$ and black infant mortality rates have consistently exceeded those of whites. These findings have come to be described graphically as a white-black health gap, the blacks remaining on the wrong side of the gap at a time when the United States prides itself on having some of the most advanced medical services in the world.

Early in her tenure as a top level administrator in the Reagan White House, Ms Margaret Heckler, then secretary of the Department of Health and Human Services, became aware of this problem. She responded by setting up a task force of senior advisers from the National Institutes of
Health "to decipher the message inherent in that disparity" and reduce excess death and illness among blacks and other minority Americans. Using mortality data from 1979 to 1981, this task force identified six causes that accounted for over four fifths of the excess deaths in blacks: cancer, cardiovascular disease and stroke, alcoholism and cirrhosis, diabetes, homicide and accidents, and infant mortality. The task force estimated that between 1979 and 1981 there were more than 59000 excess annual deaths among blacks but the report emphasised that the overall health of American blacks had improved and that their life expectancy had increased. Yet life expectancy at birth for white males was 71.5 years in 1983 , whereas it was 64.9 years for blacks-similar to that of whites before 1950 .

Other inequalities emerged from the study of infant mortality, which is 10.9 per 1000 live births in the US, comparing unfavourably with that in many other industrial nations. Furthermore, infant mortality is twice as high for blacks as for whites-20 against 10.5 per 1000 births. Included in these statistics are the figures for postneonatal mortality - that is, deaths from day 28 to 1 year of agewhich tend to reflect unhealthy living conditions and poor access to or quality of medical care. In 1983 the postneonatal mortality rate among blacks was twice that of whites- -6.6 against $3 \cdot 3$ deaths per 1000 live births.

The report was clear that blacks and other minorities had poorer health than whites. What remained unclear was the current administration's commitment to reduce this disparity. The task force made recommendations such as improving health information and education, investigating better models of health services, enlisting non-federal organisations to help, and conducting more studies of the health problems of minorities and of the lack of health professionals in their communities. Yet administration officials said that no funds could be allocated to new programmes and that actions arising from the task force's recommendations would have to be "budgetarily neutral."

Perhaps the main value of the report will be to reemphasise a continuing inequality in the distribution of medical care. An earlier study of national health statistics had already shown that poor blacks made fewer visits to doctors than their white counterparts and that they were less likely to have a private doctor or use a telephone for consultation. ${ }^{3}$ Aday and Anderson had found that non-whites were more likely to have no health insurance and no regular family doctor and less likely to have sought medical care within the past four years. ${ }^{4}$ A 1980 report to the US Civil Rights Commission showed lack of access to hospitals, doctors, and prenatal and postnatal care: it also identified linguistic barriers and poor control of quality of care as important issues in restricting good health care for minorities. ${ }^{5}$ Even earlier-in the 1940s-Gunnar Mydral had recommended that disease prevention must be planned nationally without regard to colour and that: "the application of the egalitarian principles... in the cure of disease and ill health and... equality of opportunity in their prevention ... will suffice to eliminate any special Negro disabilities." 6

As with most socioeconomic problems it is easier to set up new studies than to come up with solutions. The task force did not attack many of the complex issues contributing to this inequity in health between whites and other minorities, and how such inequalities are to be eliminated in a pluralistic society of the size and diversity of the US is by no means obvious. Clearly the core of the problem is rooted in poverty and limited opportunities, and providing equitable care in a mostly privately funded health care system at a time when the 